\title{
Design of Monitoring Lighting Counter Based on Android Application (Case Study at Tower BTS INDOSAT OOREDOO Site Utara Jepara 14JPA010)
}

\author{
Deki Renjaka Ardiyanto ${ }^{1}$, Jenny Putri Hapsari², Eka Nuryanto Budisusila ${ }^{3}$ \\ 1 Universitas Islam Sultan Agung/ Teknik Elektro \\ 2 Universitas Islam Sultan Agung/ Teknik Elektro \\ 3 Universitas Islam Sultan Agung/ Yeknik Elektro
}

\begin{abstract}
The need for information through a monitoring system on BTS tower equipment is very necessary, including monitoring lightning strike protection. To find out whether there is a strike on the BTS, usually, technicians have to come to the BTS location to see the impact of the strike in the form of damage to the arrester, or other damage and even seek information from residents around the BTS location. The location of the BTS location is far from the head office, of course this is not effective.

This research is the development of a counter lighting system designed to monitor and detect lightning strikes from a distance. By using Arduino Uno, ethernet shield, current sensor and android smart phone. The information displayed on the android smart phone is the location of the BTS tower, the time and magnitude of the strike current. The lighting protection monitoring tool based on android operation using the PZEM-004T module is a system designed and utilized to read the presence of lightning strikes which include the current flowing in the BTS tower grounding system.

The test results show that the lighting protection monitoring tool using the PZEM-004T module can measure and display the current value and when a strike occurs, in real time and stored in the database. Based on the test results, it can be concluded that the results of the design of the lighting protection monitoring tool have a deviation (error) of $9,64 \%$ and a current of $12,5 \%$.
\end{abstract}

Keywords: Arduino uno; Ethernet shielded; Android; Tower BTS

corresponding email : deki.std@unissula.ac.id

This is an open access article under the $\underline{C C B Y}$ license

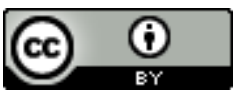

\section{INTRODUCTION}

Petir merupakan bagian indikasi alam yang dapat kita analogikan dengan suatu kondensator raksasa, semacam halnya kapasitor yang dapat menaruh tenaga sesaat (energy storage). Lighting counter ialah alat yang biasa digunakan mengetahui adanya sambaran petir dalam satu tower BTS diperlukan Lighting counter yang terpasang di system pertanahan. Mekanisme kerja lightning counter sendiri dengan menggunakan power dan induksi yang ditimbulkan adanya sambaran petir yang mengenai ujung penangkal petir yang melewati down conduktor (kabel induktor) sehingga kumparan yang terdapat dalam lighting counter akan bergerak dengan indikator angka. Pada tower BTS sering kali induksi dari sambaran petir membuat perangkat menjadi rusak dan membutuhkan proses yang cukup lama untuk klaim garansi perangkat. Kerusakan pada perangkat karena sambaran petir sering kali tidak diketahui karena tidak ada pemantauan terhadap sambaran petir, sehingga tidak dapat diketahui kapan perangkat pada tower BTS rusak.

Lighting counter ialah alat yang biasa digunakan mengetahui adanya sambaran petir dalam satu tower BTS diperlukan Lighting counter yang terpasang di system pertanahan. Mekanisme kerja lightning counter sendiri dengan menggunakan power dan induksi yang ditimbulkan adanya sambaran petir yang mengenai ujung penangkal petir yang melewati down conduktor (kabel induktor) sehingga kumparan yang terdapat dalam lighting counter akan bergerak dengan indikator angka. Pada tower BTS sering kali induksi dari sambaran petir membuat perangkat menjadi rusak dan membutuhkan proses yang cukup lama untuk klaim garansi perangkat. Kerusakan pada 
perangkat karena sambaran petir sering kali tidak diketahui karena tidak ada pemantauan terhadap sambaran petir, sehingga tidak dapat diketahui kapan perangkat pada tower BTS rusak

Pada penelitian kali ini akan dibuat adalah rancang bangun monitoring lightning counter berbasis aplikasi android. Penelitian ini menampilkan data sambaran petir dan akan menampilkanya pada smartphone android berupa informasi cuaca, data kejadian sambaran petir yang meliputi tanggal, waktu dan besaran arus sambaran, serta grafik terjadinya sambaran dalam setiap bulannya sehingga akan mendapatkan suatu trend pola sambaran petir pada titik tower BTS berada. Dengan adanya pengembangan alat tersebut akan lebih mempermudah klaim garansi perangkat BTS ketika terjadi kerusakan karena sambaran petir. Pada rancang bangun monitoring ini akan melakukan uji dengan memonitoring 2 (dua) lokasi tower dan mengintegrasi kedalam satu database yang nantinya data sambaran petir tersebut akan ditampilkan pada aplikasi android yang akan memudahkan petugas tower untuk memonitoring sambaran petir di lokasi tower BTS berada.

\section{LITERATURE REVIEW}

Setelah melakukan kajian dari beberapa penelitian ada beberapa penelitian terdahulu yang memiliki keterkaitan dengan penelitian yang akan dilakukan peneliti. Penelitian pertama yang berhasil ditemukan oleh peneliti yaitu penelitian yang dilakukan oleh [1]tentang monitoring proteksi petur berbasis website. Penelitian ini menggunakan mikrokontroler Arduino[2], sensor arus, ethernet shield[3], dan sim 800 untuk melakukan pemantauan sambaran petir. Pada penelitian ini data arus dari sambaran petir akan ditampilkan melalui website dan ada notifikasi sms melaui modul sim800[4].

Penelitian kedua dilakukan oleh yaitu Rancang Bangun Sistem Pentanahan Penangkal Petir Pada Tanah Basah dan Tanah Kering pada Menggunakan SMS Gateway[5]. Pada penelitian ini menggunakan Arduino sebagai mikrokontroller dan sensor arus PZEM-004T[6] sebagai pemantauan arus dari sambaran petir. Data sambaran petir akan dikirimkan ke smartphone menggunakan sms gateway yang dikirimkan dari modul SIM 900.

Penelitian ketiga dilakukan oleh yaitu Analisis Pemetaan Sambaran Petir akibat Bangunan BTS[7]. Terhadap Lingkungan Setempat. Untuk mendukung seluruh komponen dalam proses penceegahan kerusakan yang disebabkan adanya sambaran petir maka diperlukan adanya analisis pengkelompokan sambaran petir pada bangunan BTS bagi lingkungan setempat. Sesuai hasil overlay peta pembagian terstruktur mengenai intensitas sambaran petir memberikan intensitas petir tinggi ada di kecamatan yang banyak terdapat bangunan Tower BTS[8].

Penelitian keempat dilakukan yaitu Studi Sistem Proteksi Pentanahan Pada BTS (Base Transceiver Station)[9]. Agar terlindungi setiap teknisi bangunan dan pada setiap bagian phasa rangkaian alat-alat. Dilakukanlah pemasangan sistem proteksi pentanahan di BTS (Base Transceiver Station). Pembangunan rangkaian listrik ini mempunyai arahan untuk memberikan ruang resistansi yang rendah ke tanah (bumi) bagi arus ganguan untuk mengalir dengan arus yang relatif buat mengaktifkan alat-alat perlindungan arus lebih (Circuit Breaker/Fuse) membuka / open (Trip) dengan cepat. Pada penelitian yang dikerjakan ini menggunakan metode system proteksi pentanahan terhadap petir dan kebutuhan perlindungan terhadap sambaran petir menurut standar[10].

\section{DESIGN METHOD}

\subsection{Alur Perancangan}

Pada penelitian ini, langkah pertama adalah memetakan alur penelitian dengan membuat flowchart perancangan. Gambar 1 merupakan gambaran alur flowchart penelitian. Tujuan perancangan ini adalah untuk membuat alat Monitoring Lighting Counter Base on Android sebagai alat monitor yang diharapkan dapat menangkap arus yang disebabkan oleh sambaran petir terhadap grounding system tower BTS, yang dapat di monitor dari jarak jauh. Penelitan ini menggunakan metode eksperimen (uji coba). Eksperimen dilakukan pada perancangan blok-blok rangkaian dan software untuk menghasilkan alat sebagaimana tujuan awal. Dengan melakukan eksperimen terhadap perancangan dan pembuatan alat ini, diharapkan akan didapatkan rangkaian serta program sesuai dengan fungsi serta tujuan dari pembuatan alat ini.

Secara umum cara kerja rangkaian ini dapat dilihat pada gambar 2, penjelasan dari tiap block gambar tersebut adalah sebagai berikut:

1) Sensor arus PZEM-004T

Bagian ini berfungsi untuk menangkap arus yang dihasilkan oleh petir yang nantinya digunakan sebagai tolak ukur data.

2) Arduino Uno

Bagian ini berfungsi segabai pusat olah data atau dapat dikatakan sebgai CPU (Central Prosesing Unit), yang mana tugasnya mengolah semua data yang masuk dan data yang keluar. Bagian ini akan memeriksa input dari nilai sensor dan memberikan perintah ethernet shield untuk mengirim ke database.

3) Ethernet shield

Bagian ini berfungsi sebagai module mengirim data ke database mysql. 
JAST : Journal of Applied Science and Technology

Volume. 02 Number. 01, January 2022

ISSN : 2775-4022

http://jurnal.unissula.ac.id/index.php/JAST

4) Android

Bagian ini sebagai user interfacen monitoring.

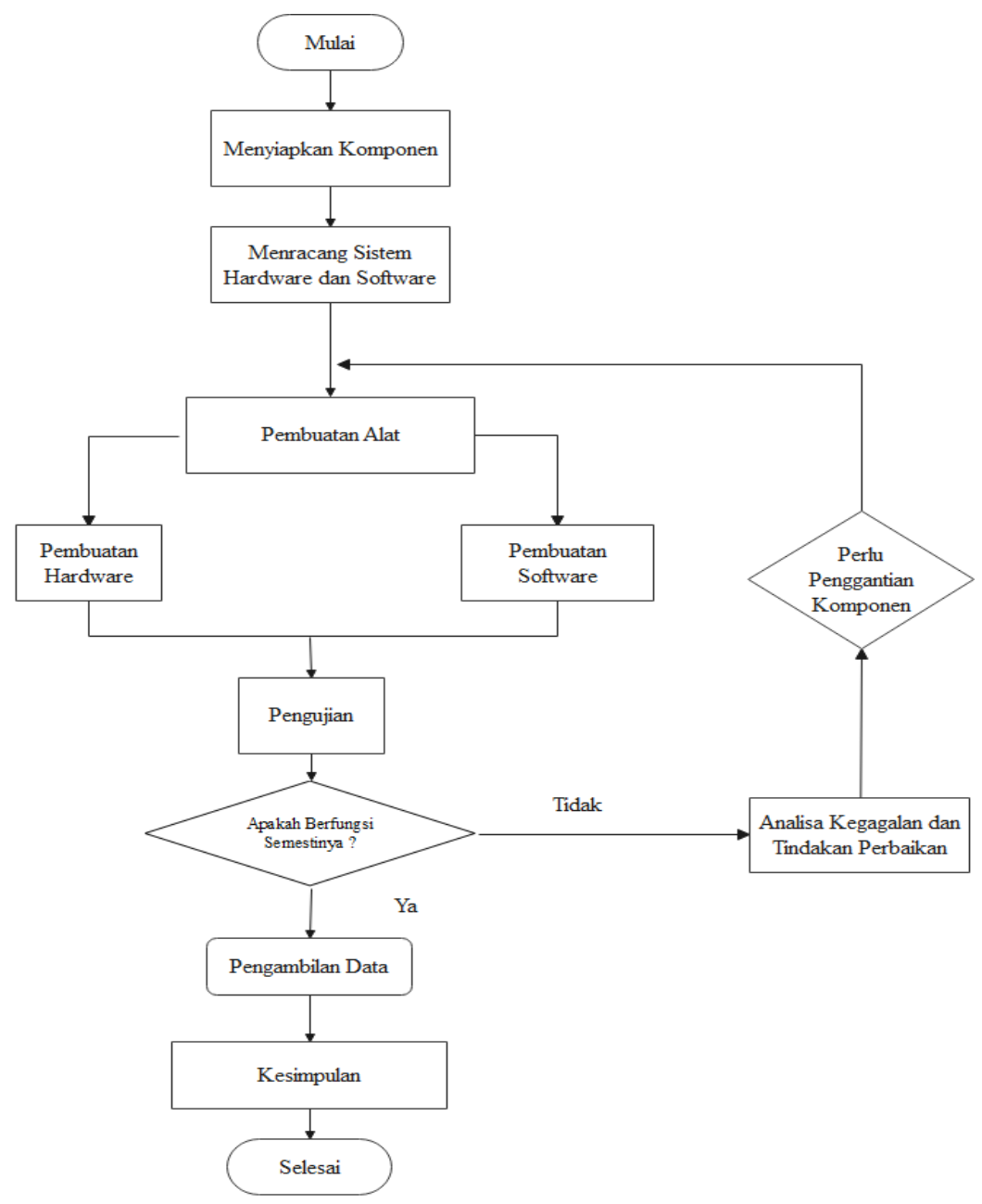

Gambar 1. Flowchart Perancangan

\begin{tabular}{|c|c|c|}
\hline \multicolumn{1}{|c|}{ Input } & \multicolumn{1}{|c|}{ Proses } & Output \\
\hline \begin{tabular}{|l|l|l|l|}
\hline $\begin{array}{l}\text { Sensor arus } \\
\text { pzem-004t }\end{array}$ \\
\hline
\end{tabular} \\
\hline
\end{tabular}

Gambar 2. Blok diagram sistem monitoring lightning counter

\subsection{Perancangan Perangkat Keras}

Komponen yang digunakan dalam pembuatan alat ini meliputi komponen elektrik. Komponen-komponen ini dapat digabungkan sebagai berikut:

- $\quad$ Sensor PZEM-004T mempunyai 4 pin (gnd, vdc, Tx dan Rx), pin Tx dan Rx dihubungkan di pin 2 dan 3 port Arduino, serta untuk sensor PZEM-004T yang ke dua dihubungkan di pin 4 dan 5 port Arduino.

- Ethernet shield dihubungkan secara seri pada module Arduino Uno.

- $\quad$ Menghubungkan antar koneksi Ethernet shiled dan PC menggunakan kabel UTP Cat6.

- Memberi catu daya 220Vac pada masing sensor PZEM-004T.

- Memberi catu daya 9 Vdc bentuk adaptor atau battrai untuk mensuplay Arduino Uno. 
JAST : Journal of Applied Science and Technology

Volume. 02 Number. 01, January 2022

ISSN : 2775-4022

http://jurnal.unissula.ac.id/index.php/JAST

Dengan mendeteksi arus yang keluar dari sambaran petir sensor arus akan membaca arus PZEM-004T dan mengirim ke arduino sehingga arduino akan mengubah data sambaran tersebut menjadi counter 1. Gambar rangkaian sensor arus dengan arduino dapat dilihat pada gambar 2.

Pada gambar 3 merupakan gambar rancangan hardware monitoring lightning counter. Rangkaian kotak akan diletakan didalam shelter atau rack BTS outdoor guna melindungi dari hujan dan panas. Dari kotak rangkaian tersebut akan langsung terhubung ke area grounding dari tower BTS.

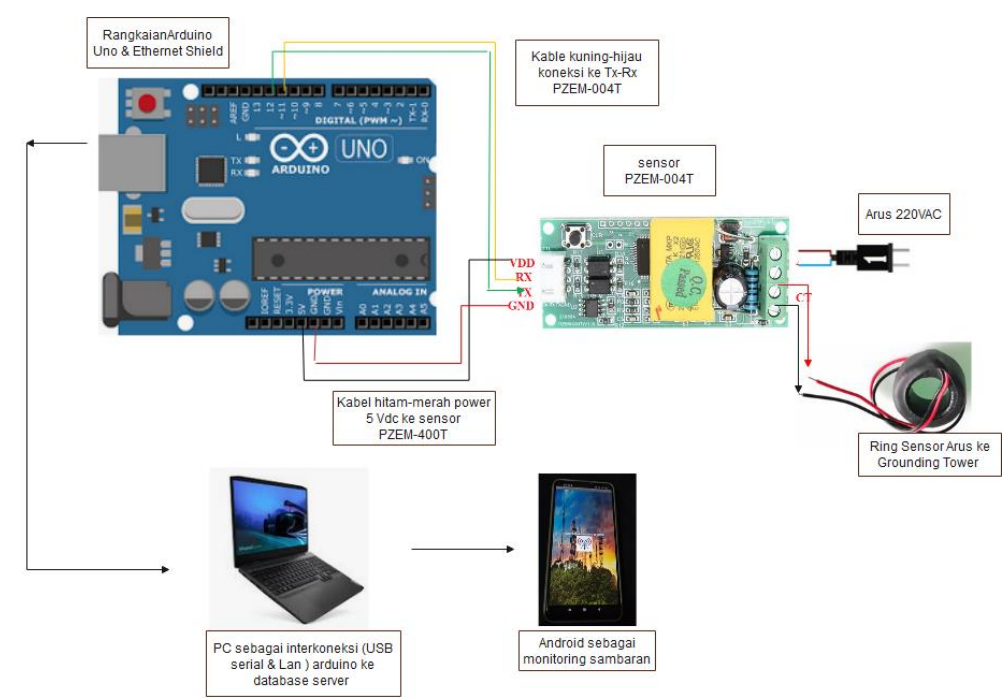

Gambar 3. Skema rangkaian sensor arus dengan Arduino Uno.

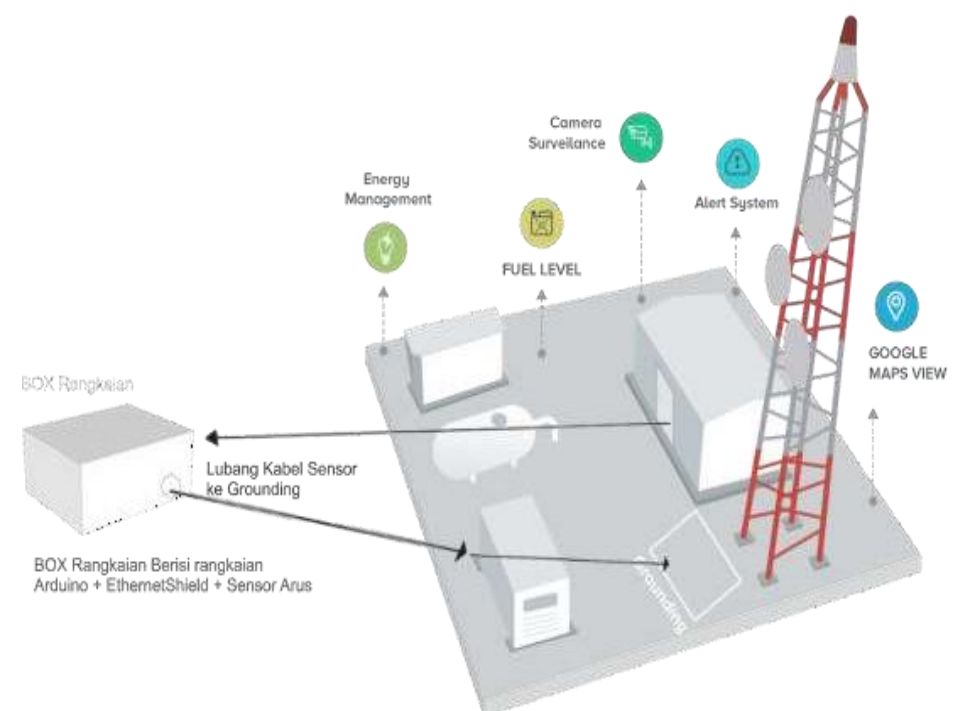

Gambar 4. Desain alat

\subsection{Perancangan Perangkat Lunak}

Perancangan perangkat lunak melalui beberapa tahap, yaitu:

1. Pemograman Arduino Uno: pemograman ini dilakukan setelah hardware sudah di rangkai.

2. Perancangan database dan Webserver: Aplikasi yang digunakan dalam perancangan database ini adalah database mysql, database tersebut diakses melalui web browser dengan mengetikkan URL http://localhost/phpmyadmin dan kemudian membuat database. Di dalam database tersebut dibuat tabel bernama "sambaran_petir", fungsi tabel tersebut untuk menampung data sensor yang dikirimkan oleh modul arduino ethernet shield. Pada tabel "data_sambar" terdapat 5 baris yang terdiri dari id (primary key), arus1, arus2, keterangan sambaran dan waktu. 
JAST : Journal of Applied Science and Technology

Volume. 02 Number. 01, January 2022

ISSN : 2775-4022

http://jurnal.unissula.ac.id/index.php/JAST

3. Perancangan user interface android: perancangan desain user interface android akan menggunakan aplikasi app inventor. Aplikasi app inventor dipilih dalam pembuatan tampilan user interface sistem monitoring ini karena penggunaanya yang sederhana dan fungsi yang cukup lengkap.

\section{RESULT AND ANALYSIST}

Hasil penelitian diperoleh dari data pengujian dari tiap-tiap blok rangkaian dan rangkaian secara menyeluruh

\subsection{Pengujian Perangkat Keras}

\subsubsection{Pengujian sensor arus PZEM-004T}

Alat ini memerlukan input tegangan sebesar 5Vdc dan Arduino memerlukan input tegangan 5V yang diperoleh dari sambungan USB pada komputer atau menggunakan adapter 9V. Pada percobaan pertama menguji fungsi kedua sensor PZEM-004T dengan cara menyambungkannya pada pin 2,3 dan pin 4,5 di board Ethernet Shield yang sudah terintegrasi dengan Arduino Uno. Pengujian ini dilakuakan untuk memastikan bahwa sensor berfungsi dengan baik. Pada kali ini dilakukan dua pengujian tegangan seperti pengujian output dan input. Adapun hasil pengujian terhadap sensor PZEM-004T dapat dilihat pada table 1.

Table 1. Pengujian sensor PZEM

\begin{tabular}{cll}
\hline No & \multicolumn{1}{c}{ Sensor PZEM-004T } & Tegangan \\
\hline 1 & Input & $221,2 \mathrm{AC}$ \\
2 & Output & $5,01 \mathrm{Vdc}$ \\
\hline
\end{tabular}

Pada kondisi ini pengukuran dilakukan dengan menggunakan volt meter untuk dapat mengetahui tegangan input pada sensor PZEM-004T. Volt meter dihubungkan pada input terminal dengan kabel warna hitam negative (-) dan kabel merah port positif (+). Sedangkan pengujian output sensor dilakukan dengan mengunakan volt meter guna mendapatkan tegangan output pada sensor. Probe positif meter dihubungkan pada vcc (+) dan port negative dihubungkan pada ground sensor PZEM-004T. Pengujian input pada sensor PZEM-004T dapat dilihat pada gambar 5 .
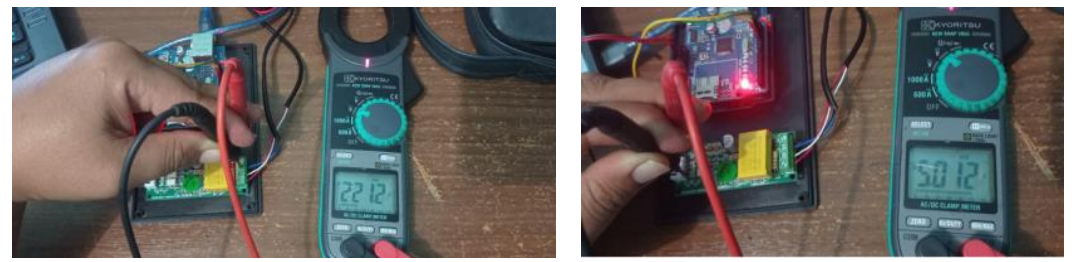

Gambar 5. Inpuut dan output sensor PZEM-004T

\subsubsection{Pengujian nilai simpangan (error) alat ukur rancangan}

Setelah dilakukan penganbilan data pengukuran arus tegangan menggunakan alat ukur standart dan alat ukur rancangan maka didapatkan table perhitungan simpangan (error) alat ukur rancangan disbanding alat ukur standart berikut ini merupakan hasil pengujian yang dilakukan. (Tabel 2), dengan perbandingan alat ukur tang ampre alat ini memiliki presentasi eror tertinggi sebesar $12,5 \%$. Pada pembacaan multimeter 2,4 A dan pembacaan sensor 2,1 A. Dengan cara yang sama didapatkan hasil pada table 4.2 dengan rata-rata eror yang bernilai $9,64 \%$ akurasi sensor ini cukup baik sehingga dapat digunakan dalam pengambilan data.

Table 2. Pengujian sensor PZEM

\begin{tabular}{ccccc}
\hline No & $\begin{array}{c}\text { Pembacaan Sensor } \\
\text { (Ampere) }\end{array}$ & $\begin{array}{c}\text { Pembacaan Multimeter } \\
\text { (Ampere) }\end{array}$ & Selisih (A) & Persentase error \% \\
\hline 1 & 2,9 & 3,2 & 0,3 & $9,38 \%$ \\
2 & 3,7 & 4,1 & 0,4 & $9,76 \%$ \\
3 & 5,2 & 5,6 & 0,4 & $7,14 \%$ \\
4 & 4,8 & 5,3 & 0,5 & $9,43 \%$ \\
5 & 2,1 & 2,4 & 0,3 & $12,5 \%$ \\
& & Rata-Rata Error & & $9,64 \%$ \\
\hline
\end{tabular}

\subsection{Pengujian Perangkat Lunak}

4.2.1 Pengujian koneksi Arduino Uno dengan sensor PZEM-00T 
JAST : Journal of Applied Science and Technology

Volume. 02 Number. 01, January 2022

ISSN : 2775-4022

http://jurnal.unissula.ac.id/index.php/JAST

Setelah proses rangkaian hardware selesai dibuat langkah selanjutnya yaitu membuat program software pada aplikasi program arduino yang telah dipersiapkan dan juga memberikan library pada masing-masing perangkat. Untuk pengujian nilai sensor dapat diamati memalui serial port monitor Arduino Uno. Untuk pengujian pertama pengukuran pada kabel ground tower di mana pada saat itu tidak ada tegangan arus yang melewati penampang kabel grounding dapat dilihat di serial monitor Arduino arus sensor bernilai 0 ampere sesuai dengan pengukuran alat tang ampere kyoritsu

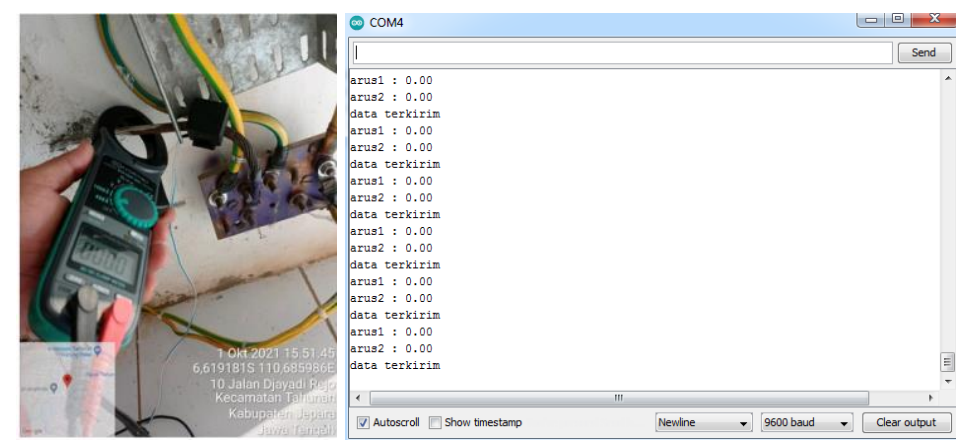

Gambar 6. Pengukuran sensor PZEM-004T dengan tang ampere dan hasil pengukuran pada kabel penghantar saat tidak ada arus

Pengujian selanjutnya dengan memberikan nilai arus pada kabel penampang yang merupakan ilustrasi adanya aliran arus yang melalui kabel tersebut dapat dilihat di serial monitor arduino arus sensor bernilai 4,7 A, sedangkang pada tang ampere terbaca 2,6 A.

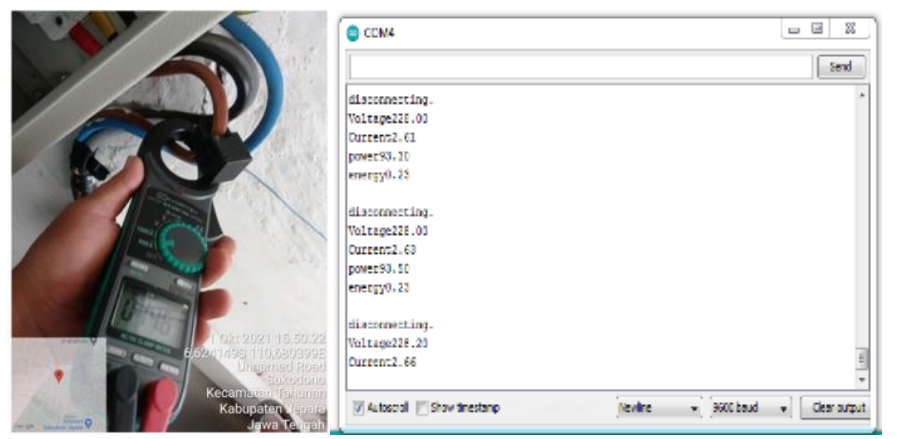

Gambar 7. Pengukuran sensor PZEM-004T dengan tang ampere dan monitor arduino dengan memberikan arus pada kabel penghantar

\subsubsection{Pengujian pengiriman data sensor ke database}

Pengujian ini bertujuan untuk mengetahui koneksifitas antara modul rangkaian Arduino, PC (host) hingga ke server database MySQL. Untuk langkah awal terlebih dahulu memberikan library dan include karakter tiap perangkat sensor serta client kedalam coding pemrograman kedalam Arduino Uno. Pengujian koneksi antara keduanya dilakukan dengan memberika konfigurasi IP ethernet shield dengan PC dengan IP address satu kelas, pengetesan koneksi dapat dilakukan dengan melakukan ping antara modul ethernet shield dengan PC, jika kedua modul ini telah terkoneksi dengan baik, maka akan muncul pesan replay pada saat melakukan perintah "ping", jika ethernet shield telah terkoneksi dengan PC monitoring, maka data sensor dapat secara otomatis masuk kedalam database. 
JAST : Journal of Applied Science and Technology

Volume. 02 Number. 01, January 2022

ISSN : 2775-4022

http://jurnal.unissula.ac.id/index.php/JAST

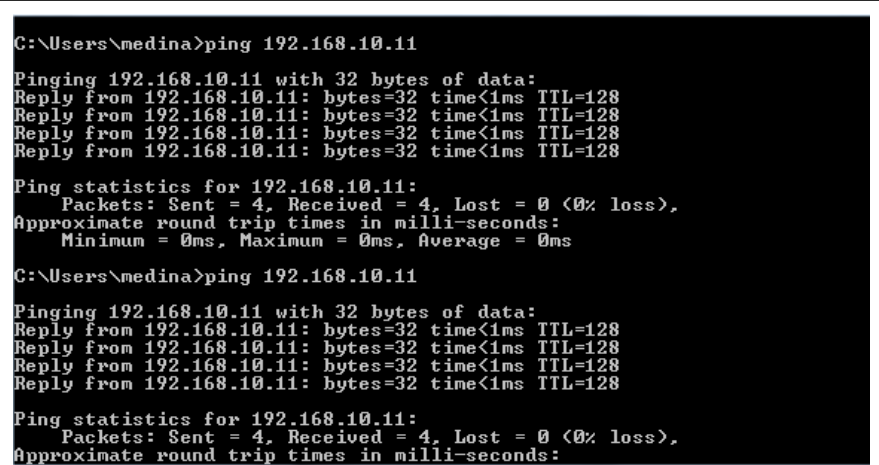

Gambar 8. Test koneksi antra PC (host) dan ethernet shiled (client)

Untuk menguji keberhasilan pengiriman data dapat juga di lihat di serial monitor port Arduino gambar 9 berikut merupakan tampilan di serial monitor aduino port.

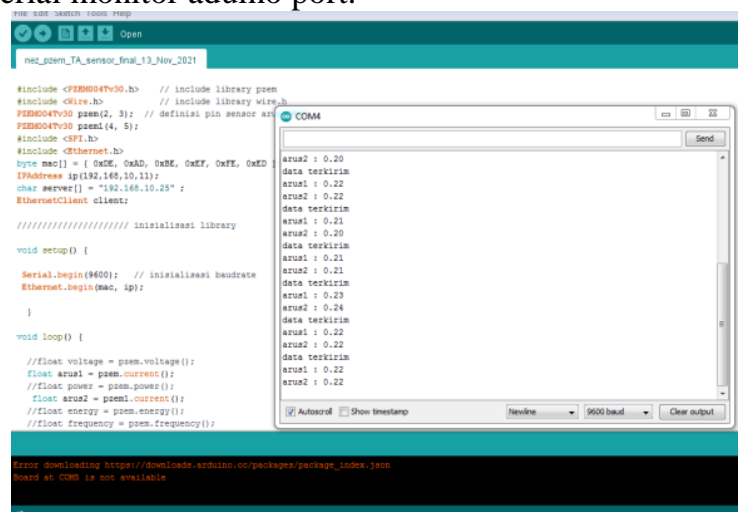

Gambar 9. Tampilan serial monitor port data berhasil di kirim ke database

Untuk menguji nilai sensor sudah terkirim ke database, dapat dilihat langsung di folder file yang telah dibuat sebelumnya.

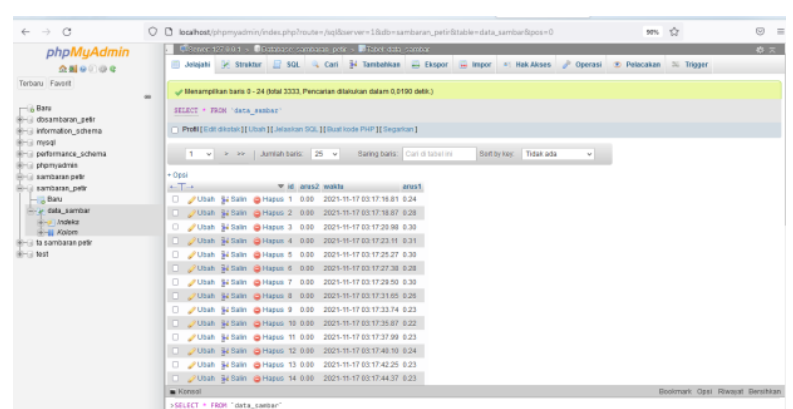

Gambar 10. Tampilan nilai sensor berhasil tersimpan database

\subsubsection{Pengujian pengiriman data sensor ke aplikasi android}

Setelah semua proses dilakukan maka perlu diuji pula kinerja aplikasi yang telah dibuat hal ini bertujuan untuk mengetahui keberhasilan aplikasi sudah terintegrasi ke database dan lama waktu yang dibutuhkan untuk proses pengiriman data sensor sampai tebaca di aplikasi user interface yang sebelumnya sudah terinstal di smart phone Android. 


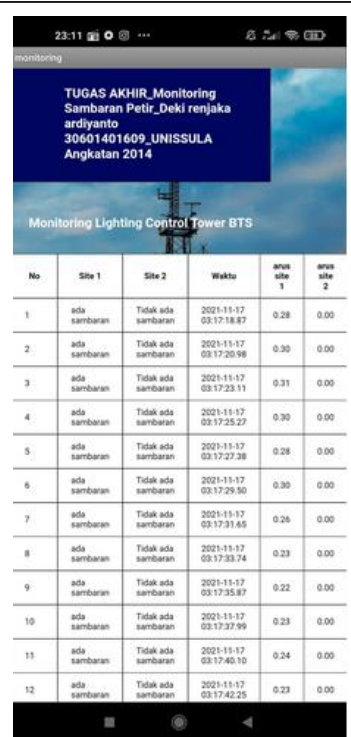

Gambar 11. Aplikasi monitoring sambaran petir berhasil membaca data_sambar database

Pada table 3 merupakan tahap Integration dan System Testing berisi pengujian secara menyeluruh kinerja rancang bangun dan untuk mengetahui sesuai atau tidaknya dengan perencanaan yang telah dibuat.

Table 3. Pengujian pengiriman data sambar pada rangkaian alat monitoring sambaran petir

\section{Kasus dan hasil uji}

\begin{tabular}{|c|c|c|c|}
\hline Data masukan & Yang diharapkan & Hasil pengamatan & Kesimpulan \\
\hline Menyalakan rangkaian alat & $\begin{array}{l}\text { Wiring kable terkoneksi } \\
\text { arduino dan pzem- } 004 \mathrm{t}\end{array}$ & $\begin{array}{l}\text { Rangkaian menyala dan } \\
\text { inikator lamp nyala }\end{array}$ & Berhasil \\
\hline $\begin{array}{l}\text { Memasukkan codding library } \\
\text { pzem-004t dan codding data } \\
\text { sensor dan ip server ke arduino }\end{array}$ & $\begin{array}{l}\text { Done compiling } \\
\text { upload done } \\
\text { arus } 0 \mathrm{~A}=\text { tidak ada } \\
\text { sambaran } \\
\text { arus } \geq 0.001 \mathrm{~A}=\text { ada } \\
\text { sambaran }\end{array}$ & Upload sucsses & Berhasil \\
\hline $\begin{array}{l}\text { Create data base ke } \\
\text { http://localhost/phpmyadmin// } \\
\text { aktifkan software xampp } \\
\text { control panel v3.3.0 }\end{array}$ & $\begin{array}{l}\text { Data base berhasil } \\
\text { dicreate Php MyAdmin } \\
\text { software xammp v3.3.0 } \\
\text { runnnig }\end{array}$ & $\begin{array}{l}\text { Indeks dan kolom data sambar } \\
\text { berhasil di create difolder } \\
\text { phpmyadmin server: } 127.0 .0 .1 \\
\text { via TCP/IP }\end{array}$ & Berhasil \\
\hline $\begin{array}{l}\text { Create software android by } \\
\text { appinventor }\end{array}$ & $\begin{array}{l}\text { Done build apk \& instal } \\
\text { di android }\end{array}$ & $\begin{array}{l}\text { Item menu data sambar \& } \\
\text { lokasi BTS tersedia di apk }\end{array}$ & Berhasil \\
\hline $\begin{array}{l}\text { Test koneksi pengiriman data } \\
\text { antara rangkaian arduino } \\
\text { ethernet shield, data base, dan } \\
\text { apk android (akses internet } \\
\text { leptop menggunakan tethering } \\
\text { wifi redmi }\end{array}$ & $\begin{array}{l}\text { Sensor pzem-004t } \\
\text { terbaca diserial monitor } \\
\text { arduino dan data sensor } \\
\text { dapat dikirim ke } \\
\text { database phpmyadmin } \\
\text { lewat sofware xammp }\end{array}$ & $\begin{array}{l}\text { Ping server local host data } \\
\text { 192.168.10.20 } \\
\text { packet sent }=4 \text {, } \\
\text { received=4, loss0\% acsses } \\
\text { (cable ethernet), open apk } \\
\text { "monitoring_petir" } \\
\text { android menampilkan menu } \\
\text { data sambaran \& data tidak ada } \\
\text { sambaran }\end{array}$ & Berhasil \\
\hline 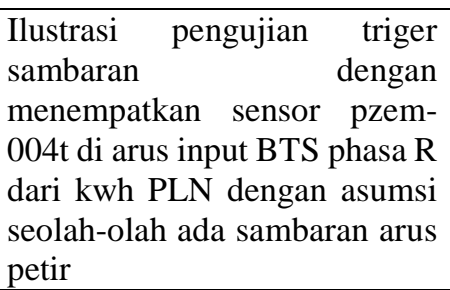 & $\begin{array}{l}\text { Open apk monitoring } \\
\text { _petir di android, pada } \\
\text { menu r monitoring } \\
\text { sambaran petir } \\
\text { menampilkan notifikasi } \\
\text { "ada sambaran" di }\end{array}$ & $\begin{array}{l}\text { Open serial monitor arduino } \\
\text { membaca sensor pzem- } 004 \mathrm{t} \\
\text { menangkap arus ... A, dan } \\
\text { dibaca codding arduino serta } \\
\text { dilanjutkan pengiriman ke } \\
\text { database lewat ethernet shield }\end{array}$ & Berhasil \\
\hline
\end{tabular}




\begin{tabular}{lll}
\hline & $\begin{array}{l}\text { waktu saat arus terbaca } \\
\text { sensor pzem-004t }\end{array}$ & $\begin{array}{l}\text { ke Phpmyadmin untuk dapat } \\
\text { diakses lewat apk android }\end{array}$ \\
\hline Ilustrasi pengujian triger & Open apk monitoring & Open serial monitor arduino Berhasil \\
sambaran dengan melepas & petir di android, pada & membaca sensor pzem-004t \\
sensor pzem-004t di arus input & menu monitoring & menangkap arus 0 A, dan \\
BTS phasa R dari panel kwh & sambaran petir dibaca codding arduino serta \\
PLN dengan asumsi seolah- & menampilkan notifikasi dilanjutkan pengiriman ke \\
olah tidak ada sambaran arus & ''tidak ada database lewat ethernet shield \\
petir & sambaran', di waktu ke phpmyadmin untuk dapat \\
& saat arus terbaca sensor diakses lewat smart phone \\
& pzem-004t & android
\end{tabular}

\section{CONCLUSION}

Dari penulisan tugas akhir berjudul rancang bangun monitoring lightning counter berbasis android dapat disimpulkan beberapa hal sebagai berikut.

1. Alat rancang bangun monitoring lighting counter berbasis android merupakan pengembanganan dari alat lighting counter yang beredar dipasaran. Dengan mengunakan module sensor arus PZEM-004T, Arduino uno, Ethernet shield, dan Smart phone android yang dirancang dapat menampilkan nilai arus sambaran, diketerangan sambaran dan waktu terjadinya sambaran yang melalui grounding system pada tower BTS serta dapat dimonitor oleh user jarak jauh sehingga dapat sedikit membantu para teknisi BTS tower untuk mempermudah investigasi dan tindakan selanjutnya.

2. Perancangan monitoring kali ini menggunakan Software MIT Appinventor untuk membangun apk yang nantinya akan di instal pada smartphone teknisi tower BTS.

3. Alat monitor yang dirancang menggunkan energi listrik, sehingga jika ada gangguan tegangan PLN off akan menonaktifkan kinerja monitor lighting counter. Untuk mengirim data sensor ke localhost phpmyamin menggunakan software xampp control panel dan hal ini tentunya membutuhkan koneksi internet dalam satu jaringan.

4. Besaran simpangan alat ukur rancangan dibandingkan dengan alat ukur standart (multimeter) untuk arus 9,64\%. Dengan demikian perhitungan arus pada sampel percobaan akurat. Sistem Monitoring Lightning Counter berbasis android berkerja dengan baik dan semestinya.

\section{REFERENCES}

[1] E. D. Hartono, "Rancang Bangun Sistem Monitoring Proteksi Petir Menggunakan Mikrokontroller Dan Berbasis Web," Konvergensi, vol. 11, no. 01, 2016, doi: 10.30996/konv.v12i2.1312.

[2] M. Ichwan, M. G. Husada, and M. Iqbal Ar Rasyid, "Pembangunan Prototipe Sistem Pengendalian Peralatan Listrik Pada Platform Android," J. Inform., vol. 4, no. 1, pp. 13-25, 2013.

[3] E. Hesti and Adewasti, "Aplikasi Android Sebagai Pengontrol Jarak Jauh Smarthome Dengan Koneksi Jaringan Internet," Tek. Elektro Politek. Negeri Sriwij., vol. 2, no. 2, pp. 157-165, 2018, [Online]. Available: http://eprints.polsri.ac.id/4534/.

[4] R. Y. Endra, A. Cucus, F. N. Afandi, and M. B. Syahputra, "Model Smart Room Dengan Menggunakan Mikrokontroler Arduino Untuk Efisiensi Sumber Daya," Explor. J. Sist. Inf. dan Telemat., vol. 10, no. 1, 2019, doi: 10.36448/jsit.v10i1.1212.

[5] H. Nawir, M. R. Djalal, and S. Sonong, "Rancang Bangun Sistem Pentanahan Penangkal Petir Pada Tanah Basah dan Tanah Kering pada Laboratorium Teknik Konversi Energi," JEEE-U (Journal Electr. Electron. Eng., vol. 2, no. 2, p. 48, 2018, doi: 10.21070/jeee-u.v2i2.1581.

[6] F. N. Habibi, S. Setiawidayat, and M. Mukhsim, "Alat Monitoring Pemakaian Energi Listrik Berbasis Android Menggunakan Modul PZEM-004T,” Pros. Semin. Nas. Teknol. Elektro Terap. 2017, vol. 01, no. 01, pp. 157-162, 2017.

[7] T. Gunawan and L. N. L. Pandiangan, "Analisis Tingkat Kerawanan Bahaya Sambaran Petir Dengan Metode Simple Additive Weighting Di Provinsi Bali," J. Meteorol. dan Geofis., vol. 15, no. 3, 2014, doi: 10.31172/jmg.v15i3.221.

[8] A. S. Grivina Yuliantika, Andri Suprayoga, "Jurnal Geodesi Undip April 2016 Jurnal Geodesi Undip April 2016 ," J. Gedesi Undip, vol. 5, no. April, pp. 200-207, 2016.

[9] S. Akhavan and V. M. Goldberg, "Clinical outcome of a fibermetal taper stem: Minimum 5-year followup," in Clinical Orthopaedics and Related Research, 2007, no. 465, pp. 106-111, doi: 10.1097/BLO.0b013e3181576080.

[10] K. Y. Nashrullah, M. B. Setyawan, and A. F. Cobantoro, "RANCANG BANGUN IoT SMART FISH FARM DENGAN KENDALI RASPBERRY PI DAN WEBCAM," Komputek, vol. 3, no. 1, p. 81, 2019, doi: 10.24269/jkt.v3i1.206. 